\title{
DISTRIBUSI DAN KEPADATAN LUMBA-LUMBA Stenella longirostris DI LAUT SAWU, NUSA TENGGARA TIMUR
}

\author{
Ria Faizah"), Dharmadi"), dan Februanty S. Purnomo*")
}

\begin{abstract}
ABSTRAK
Penelitian yang bertujuan untuk mempelajari distribusi dan kepadatan lumba-lumba Stenella Iongirostris di perairan Laut Sawu, Nusa Tenggara Timur, dilakukan pada bulan Juli dan Desember 2005. Metode yang digunakan adalah distance sampling menggunakan line transect dengan dual platiom. Hasil penelitian pada bulan Juli 2005 dengan 10 sighting menemukan Stenella longirostris 245 ekor dengan distribusi di wilayah perairan Kupang, mulut Selat Ombai, Pantar, Lembata, dan Maumere. Pada bulan Desember 2005 ditemukan 994 ekor dengan 24 sighting dan tersebar di wilayah perairan Kupang, Pantar, dan Alor. Estimasi jumlah Stenella longirostris pada bulan Juli berjumlah 71 ekor pada luas daerah $475,53 \mathrm{~km}^{2}$ dan untuk bulan Desember kepadatan berjumlah 51 pada luas daerah $400.22 \mathrm{~km}^{2}$.
\end{abstract}

\section{KATA KUNCI: distribusi, kepadatan, Stenella longirostris, Laut Sawu}

ABSTRACT: The distribution and density of spinner dolphin Stenella longirostris in Sawu Sea, East Nusa Tenggara. By: Ria Faizah, Dharmadi, and Februanty S. Purnomo

Research which aims to study of distribution and density of spinner dolphin (Stenella longirostris) in Sawu Sea, East Nusa Tenggara, was carried out in July and December 2005. This used distance sampling method with line transect with double platform. The Result of observation in July recorded 10 sighting of Stenella longirostris with number 245 individuals, which spread in Kupang water, inlet of Ombai Strait, Pantar, Lembata, and Maumere waters. In December recorded 24 sighting with number 994 individuals and distributed in Kupang water, Pantar, and Alor waters. Estimate density on July was 71 individuals on $475.53 \mathrm{~km}^{2}$ width area, while estimate density on December was 51 individuals on $400.22 \mathrm{~km}^{2}$ width area.

KEYWORDS: distribution, density, Stenella longirostris, Sawu Sea

\section{PENDAHULUAN}

Indonesia merupakan satu-satunya daerah di kawasan khatulistiwa dunia yang digunakan sebagai tempat singgah dan habitat flora fauna perairan antar samudera (Dahuri et al., 1996; Tomascik et al., 1997). Cetacea merupakan salah satu biota yang melakukan pergerakan dari Samudera Pasifik dan Samudera Hindia yang terjadi melalui terusan Kepulauan Sunda Kecil yang membentang sepanjang $900 \mathrm{~km}$ dari selat Sunda sampai dengan selat Sahul. Cetacea yang bermigrasi, menjadikan terusan tersebut sebagai tempat pergerakan lokal atau migrasi jarak jauh (Klinowska, 1991). Nilai ekologis penting dari terusan tersebut kurang dipahami, tetapi sangat mungkin digunakan sebagai jalur migrasi. Cetacean sangat rentan terhadap berbagai dampak lingkungan seperti kerusakan habitat, gangguan suara bawah permukaan, jaring perangkap, polusi laut, dan penangkapan berlebih atas sumber daya perairan (Hofman, 1995).
Perairan Indonesia memiliki sekitar 30 jenis paus dan lumba-lumba dari total 86 jenis Cetacea di dunia (Rudolph et al., 1997; Barnes, 1996; Kahn, 2003). Cetacean tersebut termasuk beberapa jenis yang populasi diklasifikasikan jarang dan dalam keadaan bahaya. Saat ini, seluruh jenis Cetacean masuk dalam daftar (Convention on International Trade of Endangered Species of Flora and Fauna). Indonesia telah meratifikasi Convention on International Trade of Endangered Species of Flora and Fauna pada tahun 1979, yang berarti bahwa Indonesia setuju untuk tidak melakukan perdagangan ekspor impor Cetacean dan produk-produk Cetacean. Selain itu, Peraturan Pemerintah 7/1999 (pengawetan jenis tumbuhan dan satwa liar) telah melindungi seluruh jenis Cetacea di Indonesia sehingga perdagangan dalam negeri tidak dapat dilakukan berdasarkan pada peraturan tersebut. Kegiatan yang boleh dilakukan adalah perburuan tradisional seperti yang selama ini dilakukan oleh masyarakat Lamalera (Barnes, 1996).

\footnotetext{
Peneliti pada Pusat Riset Perikanan Tangkap, Ancol-Jakarta

- Mahasiswa pada institut Pertanian Bogor, Bogor
} 
Salah satu famili dari Cetacea yang paling menarik perhatian dan tersebar luas di perairan dan paling sering dijumpai adalah famili Delphinidae, di mana termasuk di dalam lumbalumba Stenella longirostris atau lebih dikenal dengan Spinner dolphin. Lumba-lumba jenis Stenella longoristris dapat dibedakan melalui paruh yang panjang dan ramping, sirip dorsal yang tegak, tubuh yang panjang dan ramping, dahi yang landai, dan ekor yang panjang dan lancip. Selain itu, sangat aktif dan sering melakukan lompatan ke udara sambil berputar. Stenella longirostris memiliki 3 pola warna, abu-abu gelap pada bagian punggung, abu-abu terang pada bagian samping, dan putih (abu-abu putih) pada bagian perut (Carwardine, 1995). S. longirostris terdapat dalam jumlah yang besar, kadang berasosiasi dengan jenis $S$. attenuata maupun dengan Tursiops truncatus

Beberapa tahun terakhir ini, lumba-lumba sudah menjadi hewan buruan untuk dijadikan bahan konsumsi dan lain seperti daging paus. Ada perburuan Cetacean secara terus-menerus ini dapat mengakibatkan berkurang populasi lumbalumba di alam, meskipun dilakukan secara tradisional (Wiadnyana et al., 2005). Dalam tulisan secara spesifik dipelajari jenis Cetacean kecil yaitu lumba-lumba Stenella longirostris di perairan Sawu. Tujuan riset adalah untuk mendapatkan informasi mengenai distribusi dan kepadatan lumba-lumba Stenella longilostris di perairan ini sebagai langkah awal untuk mengkaji keberadaan dan alur migrasi populasi Cetacea di Indonesia.

\section{BAHAN DAN METODE}

Penelitian ini dilakukan pada bulan Juli dan Desember 2005. Pembagian waktu tersebut dilakukan berdasarkan pada kondisi lingkungan perairan dan tradisi waktu berburu paus nelayan tradisional Desa Lamalera yang dilakukan pada bulan Mei sampai dengan Nopember.

Pengamatan objek dilakukan secara visual dari atas kapal dengan kecepatan 6 sampai dengan 7 knot dengan menggunakan kapal KLM fRatu Rima yang berukuran panjang $21 \mathrm{~m}$ dan lebar 4,5 $\mathrm{m}$ dengan menggunakan mesin Yanmar 45 pk.

Metode yang dipakai dalam penelitian ini adalah distance sampling dengan line transects, menggunakan pengamatan dengan 2 kelompok pengamat (dual platform atau double observer). Metode line transect zig-zag bertujuan untuk memperoleh estimasi kepadatan jenis Cetacea, selain itu cakupan wilayah penelitian menjadi lebih luas dan tidak ada yang terlewat, serta data juga dapat digunakan untuk melihat distribusi dari Cetacea. Asumsi yang digunakan untuk pendugaan kelimpahan pada line transects survei adalah bahwa seluruh binatang yang ada pada jalur survei dilihat oleh para pengamat (Hammond et al., 2002).

Survei pada bulan July 2005 dibagi menjadi 5 sektor, sedangkan pada bulan Desember 2005 dibagi menjadi 4 sektor (Gambar 1a dan 1b).

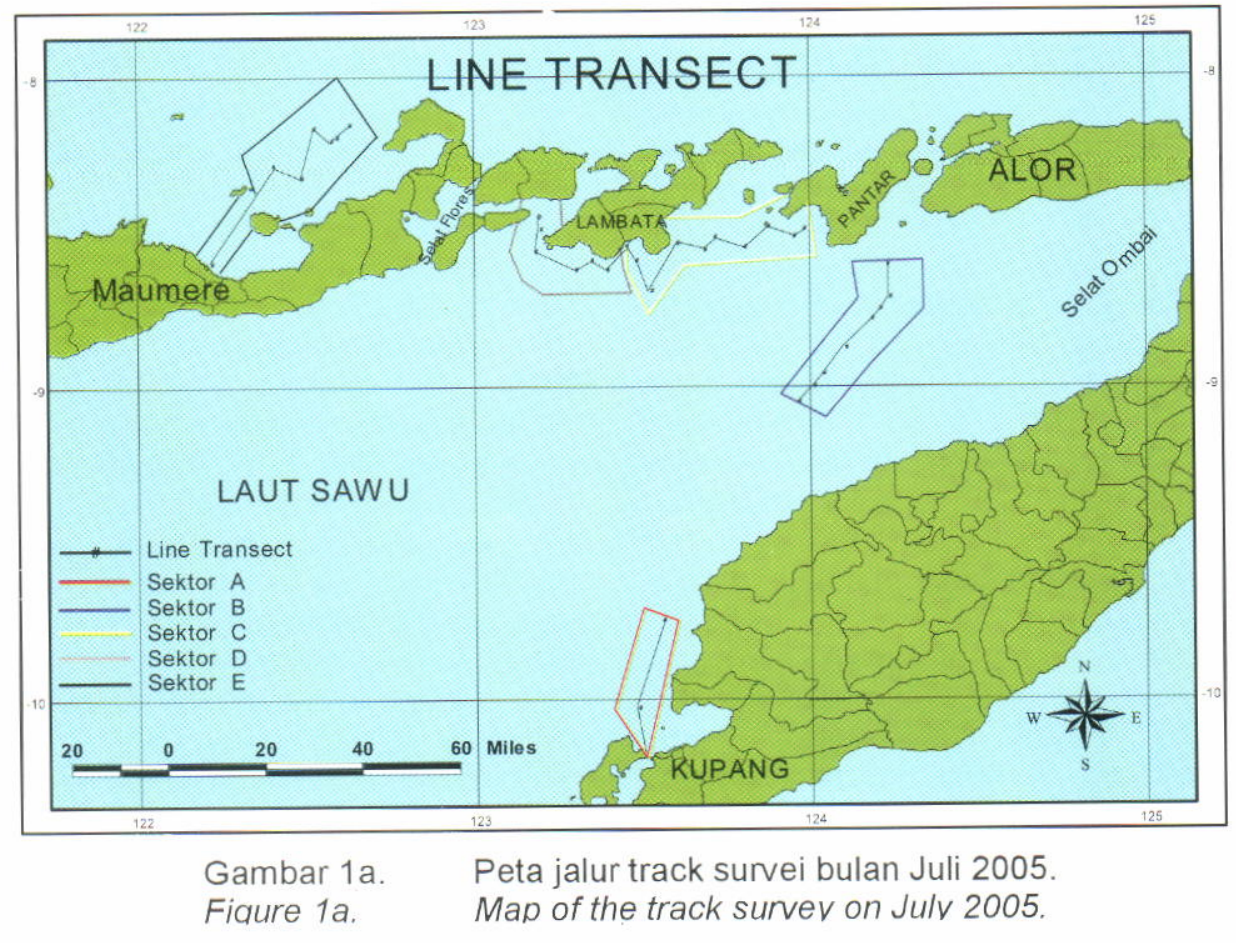




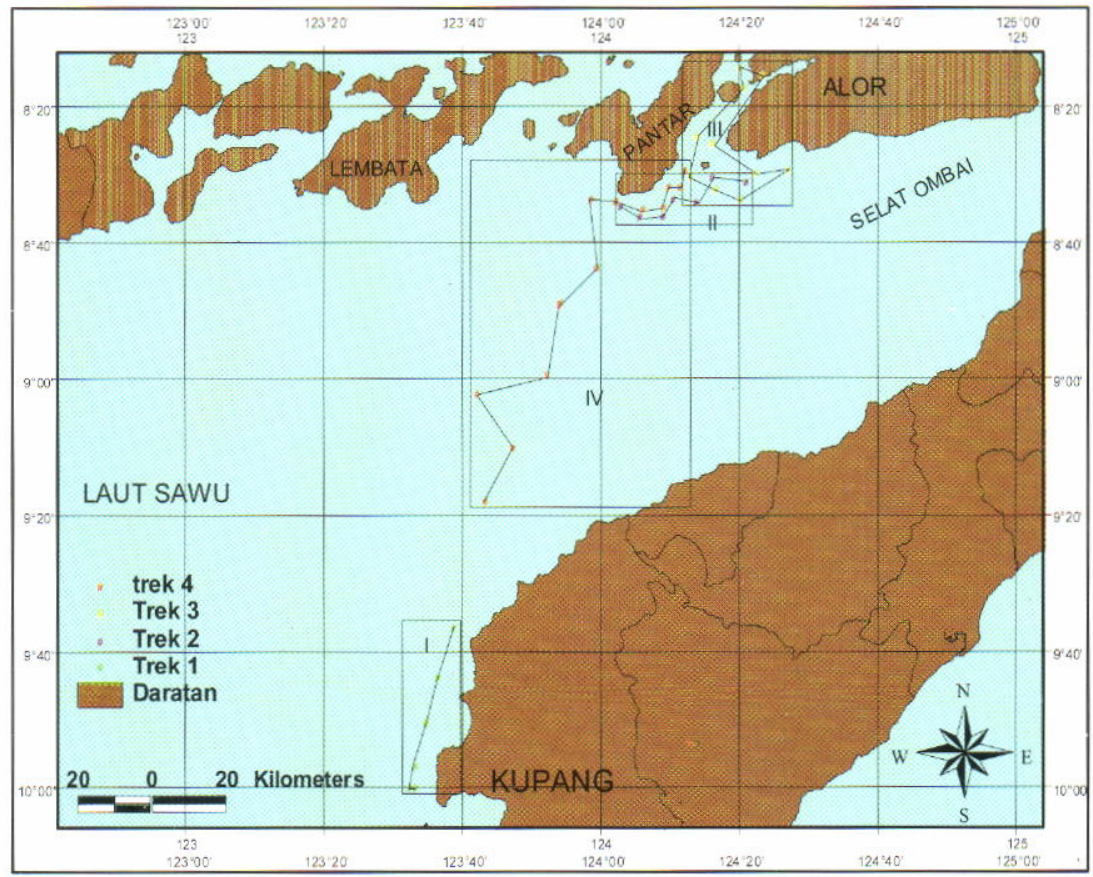

Gambar 1b. Peta jalur track survei bulan Desember 2005 Figure1b. Map of the track survey on December 2005.

Pada saat pengamatan, data yang diambil adalah spesies, jumlah, tanggal, dan waktu pengamatan, posisi GPS, sudut objek dengan kapal, jarak obyek dari kapal dan arah renang Cetacea, keberadaan anak beserta jumlah, keadaan laut saat pengamatan, asosiasi spesies, dan beberapa tingkah laku dari Cetacea.

Koordinat geografis pengamatan berasal dari koordinat kapal. Untuk mengetahui koordinat sesungguhnya dari sasaran, maka dilakukan konversi dari derajat lintang bujur kapal dengan sudut sasaran terhadap haluan dan perkiraan jarak langsung dari pengamat ke sasaran. Dengan mengetahui jarak tegak lurus dari kapal ke sasaran, maka diperoleh titik perkiraan di mana sasaran pertama dilihat. Untuk mengetahui perhitungan detil jarak tegak lurus, dapat dilihat pada Gambar 2.

Data pengamatan yang diperoleh dianalisis dengan menggunakan software DISTANCE untuk menentukan estimasi kepadatan Cetacea. Secara statistika, estimasi kepadatan dapat dihitung

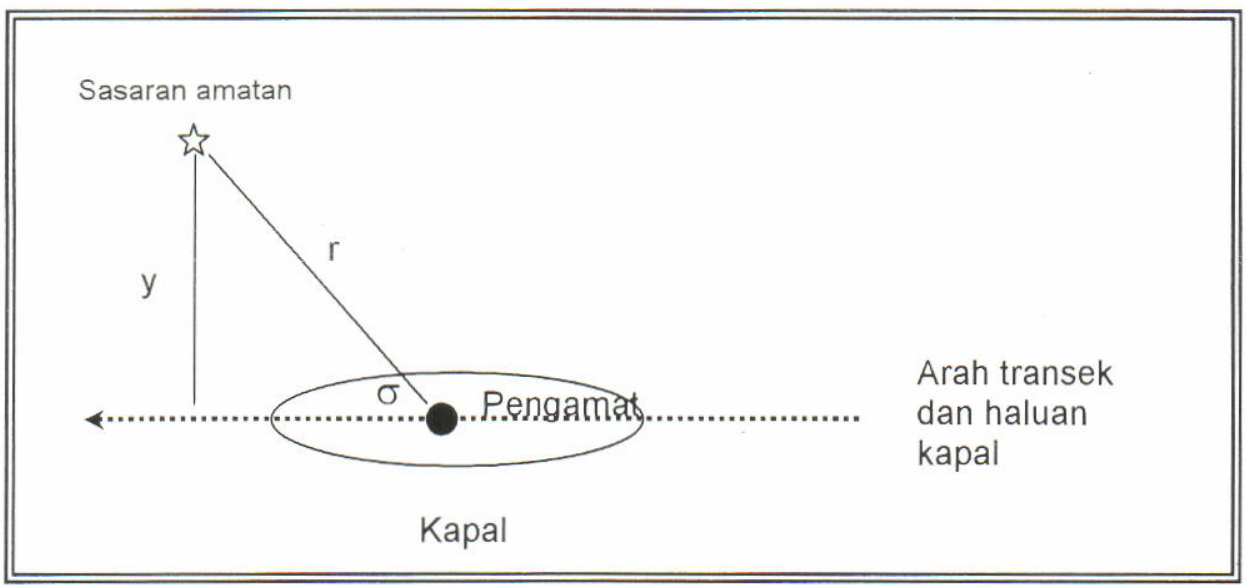

Gambar 2. Perhitungan jarak tegak lurus (perpendicular distance).

Figure 2. Formula of perpendicular distance.

Keterangan/Remarks: Jarak tegak lurus $=y=r \sin \sigma ; R=$ perkiraan jarak dari pengamat ke sasaran; $\sigma=$ perkiraan sudut antara haluan kapal dengan sasaran 
dengan formula sebagai berikut:

$$
\frac{\hat{D}=N}{A}
$$

di mana:

$$
\begin{aligned}
& \hat{D}=\text { estimasi kepadatan Cetacea } \\
& N=\text { jumlah individu yang tercatat } \\
& A=\text { luas daerah survei }=2 \mathrm{WL} \\
& W=\text { lebar transek } \\
& L=\text { panjang transek }
\end{aligned}
$$

\section{HASIL DAN BAHASAN}

\section{Distribusi Stenella longirostris}

Hasil penelitian pada bulan Juli 2005 yang meliputi wilayah perairán Kupang, Pantar, Lembata, dan Maumere, ditemukan Spinner dolphin (Stenella longirostris) 245 ekor. Distribusi Stenella longirostris pada bulan Juli tersebut pada peta Gambar 3, tersebar di setiap sektor pengamatan dengan jumlah dan frekuensi kemunculan yang berbeda. Distribusi dengan jumlah terbanyak berada di perairan Kupang, dan yang paling sedikit berada di perairan Maumere.
Total pengamatan pada bulan ini diperoleh 10 data kemunculan (sighting), di mana kondisi cuaca cerah tak berawan sehingga jarak pandang cukup jauh dan kondisi perairan pada saat itu tenang dengan skala beaufort berkisar antara 1 sampai dengan 2 , cukup mendukung untuk melakukan pengamatan secara visual. Tingkah laku lumbalumba selama pengamatan adalah aerial (melompat ke udara), traveling (berenang ke suatu arah tertentu), dan hunting (berburu).

Pada pengamatan sektor pertama ditemukan 3 sighting (kemunculan) Spinner dolphin dengan jumlah 68 ekor di perairan Kupang, pengamatan sektor 2 mendapatkan 2 sighting berjumlah 36 ekor di mulut Selat Ombai serta pengamatan sektor 3 juga mendapatkan 2 sighting berjumlah 52 ekor di antara perairan Pantar dan Lembata. Selanjutnya, pengamatan sektor 4 didapat 2 sighting 59 ekor di perairan Lembata dan pada pengamatan sektor 5 di perairan Maumere di dapat 1 sighting 30 ekor (Tabel 1). Pada Table 1 terlihat bahwa kelompok lumba-lumba ditemukan paling banyak pada kisaran 1 sampai dengan 15 ekor.

Pada bulan Desember 2005 jumlah total Spinner dolphin yang ditemukan 994 ekor, pengamatan

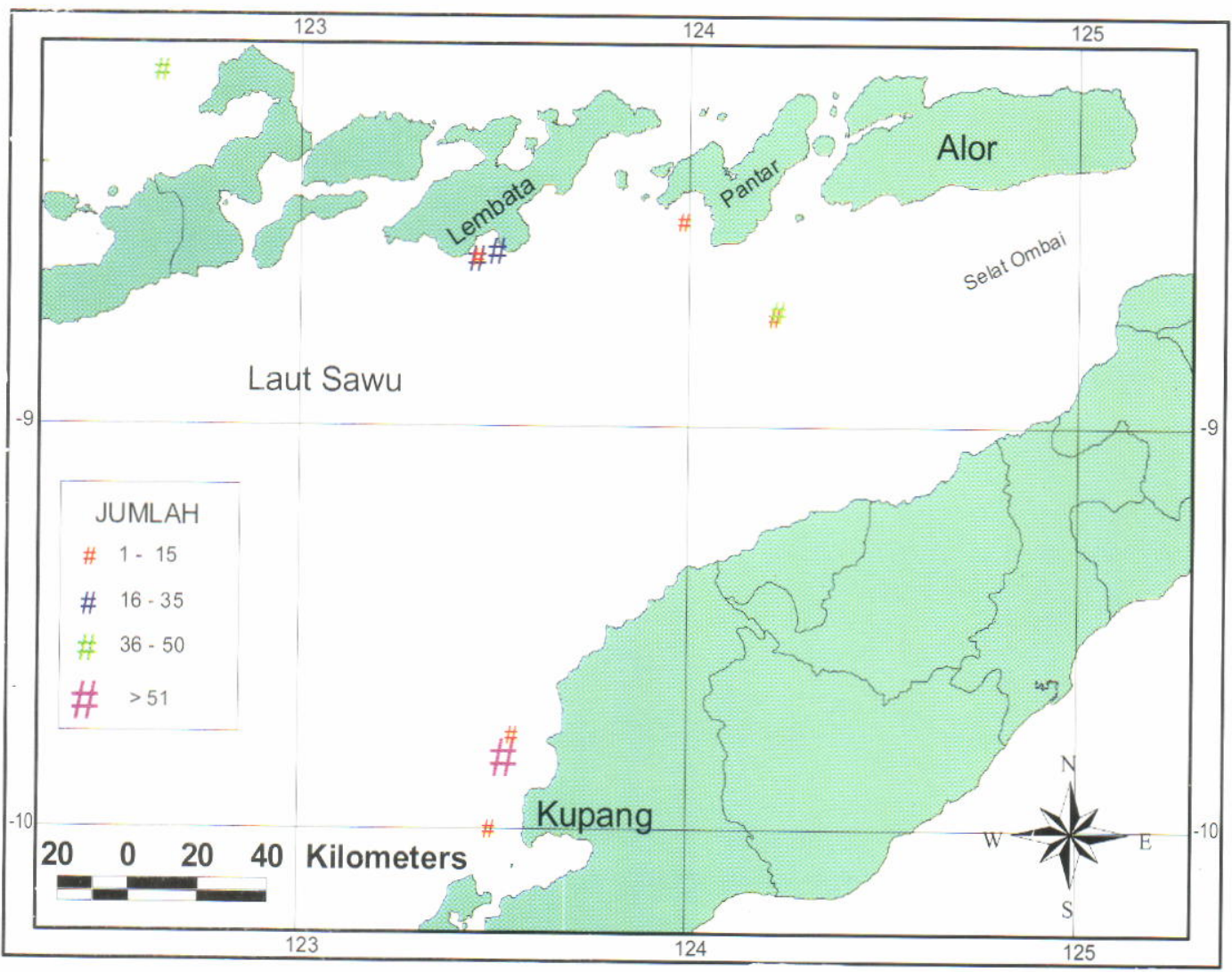

Gambar 3.

Figure 3.

Distribusi Stenella longirostris bulan Juli 2005.

Distribution of Stenella longirostris in July 2005. 
Tabel 1. Data kemunculan Spinner dolphin bulan Juli Sighting data of Spinner dolphine in July

\begin{tabular}{ccccc}
\hline $\begin{array}{c}\text { Sektor pengamatan } \\
\text { (observation sector) }\end{array}$ & \multicolumn{4}{c}{ Kelompok (schooling) } \\
\cline { 2 - 5 } 1 & $\mathbf{1 - 1 5}$ & $\mathbf{1 6 - 3 5}$ & $\mathbf{3 6 - 5 0}$ & $\mathbf{3 1}$ \\
2 & 2 & & & 1 \\
3 & 1 & 1 & 1 \\
4 & 1 & & 1 \\
5 & 1 & & & \\
\hline
\end{tabular}

pengamatan sektor pertama ditemukan Spinner dolphin 182 ekor dalam 1 sighting di sekitar perairan Kupang, selanjutnya pengamatan sektor ke-2 menemukan 7 sighting 548 ekor, pengamatan sektor ke-3 terdapat 157 ekor dengan 7 sighting. Serta pengamatan sektor ke-4 didapat 107 ekor dalam 9 sighting (Tabel 2). Pada Tabel 2 juga terlihat pola yang sama seperti pada bulan Juli yaitu paling banyak ditemukan pada kisaran 1 sampai dengan 15 ekor.

Dari 2 tabel di atas lumba-lumba Spinner banyak ditemukan dalam kelompok kecil, hanya beberapa yang terlihat dalam kelompok besar, hal ini bukan berarti bahwa lumba-lumba Spinner di perairan Alor didominasi oleh kelompok kecil. Hal tersebut, dapat terjadi karena pengamatan secara visual hanya mencatat kemunculan biota di permukaan, maka lumba-lumba yang berada dibawah air tidak terhitung atau tercatat.

Berdasarkan pada sebaran distribusi pada bulan Juli dan Desember terlihat bahwa Stenella longirostris tersebar hampir di semua wilayah perairan Laut Sawu, yang terkonsentrasi di daerah Pantar dan Alor. Pada Gambar 4 terlihat bahwa distribusi Stenella longirostris tersebar merata di perairan Laut Sawu, mulai dari perairan Kupang sampai dengan Alor dan Pantar. Secara keseluruhan, jumlah dan frekuensi kemunculan terbanyak ditemukan di perairan Pantar 567 ekor dengan 11 kemunculan.
Fenomena ini memberi gambaran bahwa daerah perairan Pantar dan Alor dapat dikategorikan sebagai daerah agregasi dari Stenella longirostris, namun hal tersebut harus diperkuat dengan penelitian lanjutan yang meliputi beberapa parameter lingkungan dan parameter pendukung lain untuk dapat memastikan apakah memang benar daerah tersebut adalah daerah agregasi, dan apa yang menyebabkan daerah tersebut menjadi daerah agregasi. Leatherwood \& Reeves (1990) mengatakan bahwa distribusi lumba-lumba di daerah tempat tinggal dapat berubah-ubah secara musiman, diduga ada 3 faktor yang mempengaruhi yaitu perubahan distribusi musiman dari mangsa, ada tekanan predator dan kebutuhan reproduksi.

Tingkah laku lumba-lumba selama pengamatan adalah aerial, schooling, dan travelling, looging (berenang di tempat sambil memunculkan kepala ke permukaan berulang-ulang) dan hunting (berburu) (Gambar 5).

Aktivitas lumba-lumba yang muncul ke permukaan tidak tergantung pada kondisi cuaca, meskipun pada saat cuaca berawan, mendung, atau hujan populasi cetacean kecil tersebut tetap menampakan diri. Hal ini, berkaitan dengan aktivitas karena harus mencari makan, melakukan perjalanan (traveling) atau berenang-renang di tempat sambil mencelup-celupkan badan. Menurut Carwardine (1995) Stenella longirostris

Tabel 2. Data kemunculan Spinner dolphin bulan Desember Sighting data of Spinner dolphin in December

\begin{tabular}{cccccc}
\hline \multirow{2}{*}{$\begin{array}{c}\text { Sektor Pengamatan } \\
\text { (observation sector) }\end{array}$} & \multicolumn{5}{c}{ Kelompok (Schooling) } \\
\cline { 2 - 6 } & $\mathbf{1 - 1 5}$ & $\mathbf{1 6 - 3 5}$ & $\mathbf{3 6 - 1 0 0}$ & $\mathbf{1 0 1 - 2 0 0}$ & $>\mathbf{3 0 0}$ \\
\hline 1 & 2 & 2 & 1 & 1 & 1 \\
2 & 5 & 1 & 1 & & \\
4 & 8 & & 1 & & \\
\hline
\end{tabular}




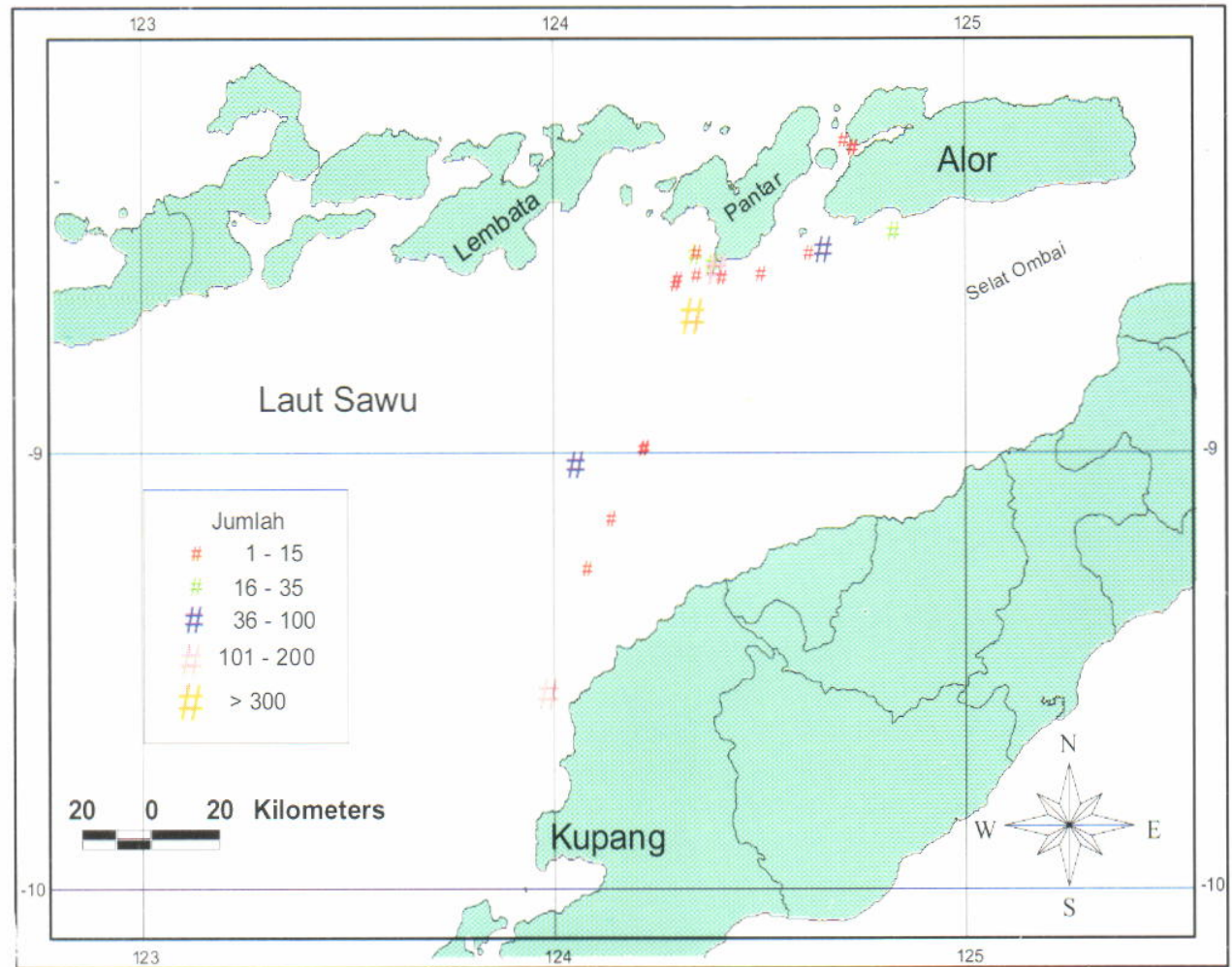

Gambar 4

Figure 4.

Distribusi Stenella longirostris bulan Desember 2005.

Distribution of Stenella longirostris on December 2005.

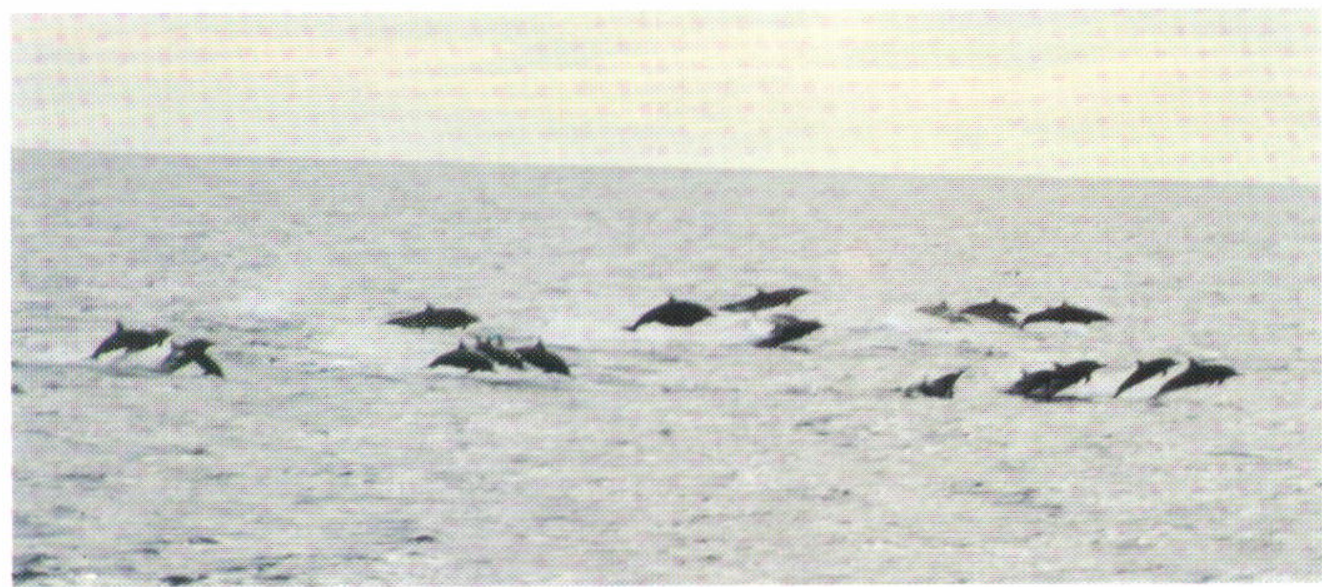

Gambar 5

Kelompok Spinner (Stenella longirostris) di perairan Alor-Nusa Tenggara Timur.

Figure 5.

Schooling Spinner (Stenella Iongirostris) in Alor Waters-Nusa Tenggara Timur.

merupakan spesies yang sangat aktif, sehingga terkadang kawanan (schooling) terlihat dari jauh karena buih-buih yang disebabkan oleh lompatan. Spesies ini sering melempar diri ke udara sampai dengan $3 \mathrm{~m}$, kemudian memutar tubuh membentuk kurva atau lingkaran pada garis longitudinal sampai dengan 7 kali dalam 1 Iompatan.

Penyebaran Stenella longirostris sangat luas mulai dari daerah laut tropis seperti Samudera
Hindia, Samudera Atlantik, Laut Karibia, dan Samudera Pasifik. Hewan-hewan itu hidup pada suhu 24 sampai dengan $30^{\circ} \mathrm{C}$ dan pada umumnya hidup di laut dan samudera, tapi kadang-kadang hidup di daerah pantai (Bruyns, 1971).

\section{Estimasi Kepadatan}

Estimasi kepadatan yang diperoleh pada pengamatan bulan Juli 2005 di perairan Alor (10 pengamatan) adalah sebagai berikut $D=0,15$ dan 
$N=71$. Hasil tersebut menunjukkan bahwa estimasi kepadatan untuk Stenella longirostris di wilayah penelitian 0,15 dan estimasi jumlah Stenella longirostris di lahan tersebut 71 ekor pada luas daerah pengamatan $475,53 \mathrm{~km}^{2}$. Estimasi kepadatan Stenella longirostris di perairan Pantar Selatan-Alor, Nusa Tenggara Timur pada bulan Desember 2005 dengan 24 pengamatan adalah 0,13 dengan estimasi jumlah 51 ekor pada luas daerah pengamatan $400,22 \mathrm{~km}^{2}$. Hal tersebut, menunjukkan bahwa kepadatan bulan Juli dan bulan Desember relatif sama dengan luas daerah penelitian yang berbeda. Dari hasil ini diperoleh gambaran bahwa lumba-lumba $S$. longirostris cenderung menetap di perairan Sawu dan sekitar.

\section{KESIMPULAN}

1. Distribusi lumba-lumba spinner tersebar merata dengan jumlah dan frekuensi kemunculan yang berbeda mulai dari KupangAlor-Pantar-Lembata-Maumere.

2. Pada bulan Juli di perairan Kupang merupakan daerah dengan jumlah lumbalumba terbanyak yaitu 68 ekor, dan jumlah terkecil ditemukan di Perairan Maumere 30 ekor. Pada bulan Desember daerah dengan jumlah lumba-lumba terbanyak adalah perairan Pantar 567 ekor dan terkecil di perairan Alor 157 ekor.

3. Kepadatan Stenella longirostris pada bulan Juli dan bulan Desember relatif sama dengan luas daerah penelitian yang berbeda.

\section{DAFTAR PUSTAKA}

Barnes, R. H: 1996. Sea hunters of Indonesia: Fishers and weavers of Lamalera. New York. Oxford University Press.

Bruyns, W. F. J. 1971. Field guide of whales and dolphin. Uitgeverij tor/n. v. uitgeverij v. h. c. a. mees ziesiniskade $14^{i l}$ Amsterdam Netherlands.

Carwardine, M. 1995. Eyewitness hand book whale, dolphin and porpoises. Dorling Kindersley Ltd. New York.

Dahuri, R., Rais, J., S. P. Ginting, \& M. J. Sitepu, 1997. Pengelolaan sumber daya wilayah pesisir dan lautan secara terpadu. Pradnya Paramita. $305 p$.

Hammond, P. S., Berggren, P., Bunke, H., Borchers, D. L., Collet, A., Heide-Jorgensen, M. P., Heimlich, S., Hiby, A. R., Leopold, M. F., \& Oien, U. 2002. Abundance of harbour porpoise and other Cetaceas in the North Sea and adjecent waters. Journal of Applied Ecology 2002. British Ecological Society. p 361-376.

Hofman. R. J. 1995. The changing focus of marine mammal conservation. Trends. Ecol \& Evol. Vol.10 No.11: 462-465.

Kahn, B. 2003. Cetacean species positively identified to date in Indonesia [online]. Apex Environmental. Available from http://www.apexenvironmental.com/Listlndone sia.htm|\#ID-INDONESIA [6 January 2003].

Klinowska, M. 1991. Dolphins, porpoises and whales of the world. The IUCN red data book. IUCN. Gland Switserland and Cambridge. U. K. Viii+429 p.

Leatherwood, S. \& R. R. Reeves. 1990. Bottlenose Dolphin. Academic Press. Inc.

Rudolph, P., Smeenk C. \& Leatherwood S. 1997. Preliminary checklist of Cetacean in the Indonesian Archipelago and adjacent waters, Zoologische Verhandelingen, 312. 3-48.

Tomascik, T., A. J. Mah, A. Nontji, \& M. K. Moosa. 1997. The Ecology of the Indonesian Seas. Part 1-2. Periplus Editions *HK) Ltd.

Wiadnyana, N., F. S. Purnomo, R. Faizah, P. L. Mustika, D. Oktaviani, \& M. M. Wahyono. 2004. Aquatic mammals assessment in Indonesian water. Proceeding of International Symposium on SEASTAR 2000 and Biologing Science. Bangkok 
